\title{
THE IMPACTS OF MILITARY BASE CLOSURES AND REALIGNMENTS WITH SOME EXAMPLES BASED ON LOCAL REVITALIZATION PROGRAMS IN POLAND
}

\section{MARZENA PIOTROWSKA-TRYBULL}

Faculty of Management and Command,

War Studies University in Warsaw, Poland

m.trybull@akademia.mil.pl

\author{
ARANKA IGNASIAK-SZULC \\ Faculty of Economic Sciences and Management, \\ Nicolaus Copernicus University in Toruń, Poland \\ aranka@umk.pl
}

KEYWORDS: MILITARY BASE CLOSURES AND ALIGNMENTS, LOCAL REVITALIZATION PROGRAMS IN POLAND, REVITALIZATION PROCESS.

For citation: Piotrowska-Trybull, M., Ignasiak-Szulc, A. (2019). The Impacts of Military Base Closures and Realignments With Some Examples Based on Local Revitalization Programs in Poland, Globalization And Business, №8, pp. 170-177.

https://doi.org/10.35945/gb.2019.08.022

\section{INTRODUCTION}

In the literature in the field of economic sciences (including defense economics) one can find examples of the restructuring of armed forces (military bases/units), arms industry and related research and development units and their consequences for the community on the micro, meso and macroeconomic scales, from the United States of America, the Federal Republic of Germany, Sweden, the Great Britain, France, Central and Eastern Europe (Intriligator 2001, p. 345347, Myrttinen 2003).

The process of transforming the armed forces in individual countries made itself felt at the end of the 1980s, in particular after the end of the Cold War (Markusen, Oden 1994, p. 4). The consequences of the transformations varied depending on: the strength and nature of the links between the armed forces and the local and regional community, development conditions in particular parts of the country (Myrttinen 2003 , p. 12-13), as well as the scale of reduction of defense spending. Referring to the effects of lowering these expenditures, it is worth emphasizing that the concentration of military activity in selected locations (Cunnigham, Klemmer 1995, p. 33) and the related concentration of military expenditures (as opposed to other types of public spending) may have a greater impact on the local and regional economy than on the national one. Depending on the connections of operational subsystems elements and support, as well as their distribution in space, expenditure reduction is also felt by the cities where the sub-suppliers are located, like military-industrial complex in the USA - cooperation of major suppliers with the government and smaller sub-suppliers; and services for the army from companies located throughout the country (Stankiewicz 1999, p. 27; Sirko, Piotrowska-Trybull 2013, p. 141-144).

As a result of the restructuring of the army after 1990 in the countries of Central and Eastern Europe, including Poland, some problems occurred, among others connected with: establishing land ownership, finding an investor interested in development of former military bases, environmental pollution in the areas of former military bases, lack of local adaptation capacities in local governments, as well as the problems of population dislocations.

\section{THE POSSIBLE IMPACTS OF MILITARY BASE CLOSURES AND ALIGNMENTS}

The following areas are indicated in the literature showing the effects of the liquidation of the army for the territorial unit:

- demography - population decline, decrease in population growth, population migration;

- labor market - employment decline, increase in unemployment, need for retraining;

- income situation - lowering the level of remuneration, including among those that cooperated with the liquidated 
entity, lowering the purchasing power of the population and reducing consumption, increased demand for social assistance;

- economy - changes in the economic structure, reduction in the size of the local tax base;

- public services - reduction of the number of recipients (schools, health centers, cultural institutions), sometimes also liquidation of branches due to too high costs of their maintenance in relation to the number of recipients;

- real estate market - surplus of housing supply in relation to demand, lowering property prices, worse financial situation of borrowers, increase in the number of vacant space.

The liquidation of military units from the point of view of the real estate market gives diverse possibilities of using post-military property for civil purposes, depending on its type, technical condition and location (see tab. 1).

Table 1. Examples of use of post-military assets as experienced in the Federal Republic of Germany after the departure of American troops

\begin{tabular}{|c|c|}
\hline $\begin{array}{c}\text { Type of land } \\
\text { and/or real } \\
\text { estate }\end{array}$ & $\begin{array}{c}\text { The use of post-military property } \\
\text { and related difficulties }\end{array}$ \\
\hline $\begin{array}{l}\text { Military } \\
\text { barracks }\end{array}$ & $\begin{array}{c}\text { Apartments, schools, administrative buildings } \\
\text { There are difficulties in attracting investors and using } \\
\text { the space associated with warehouses and sports } \\
\text { facilities }\end{array}$ \\
\hline $\begin{array}{l}\text { Staff } \\
\text { apartments } \\
\text { and flats }\end{array}$ & $\begin{array}{l}\text { Flats } \\
\text { The limitation is the cost of housing adaptation to } \\
\text { current market standards }\end{array}$ \\
\hline $\begin{array}{c}\text { Training } \\
\text { grounds } \\
\text { and training } \\
\text { facilities }\end{array}$ & $\begin{array}{c}\text { For training purposes of the army. Parks, reservations } \\
\text { There are restrictions on the use due to unexploded } \\
\text { ordnance, surface pollution, rare plant and animal } \\
\text { species }\end{array}$ \\
\hline Airports & $\begin{array}{l}\text { Maintaining the previous function - handling } \\
\text { passenger and freight traffic, as well as dividing the } \\
\text { area into smaller plots. } \\
\text { Sometimes there is no need to maintain the airport } \\
\text { due to: costs, other developed branches of transport } \\
\text { (railway), resistance of inhabitants concerned about } \\
\text { noise, pollution }\end{array}$ \\
\hline $\begin{array}{l}\text { Facilities for } \\
\text { the repair } \\
\text { of military } \\
\text { equipment }\end{array}$ & $\begin{array}{l}\text { Production or repairs, civil applications. } \\
\text { Difficulties of conversion of production and services to } \\
\text { civilian purposes due to dated assets }\end{array}$ \\
\hline Arsenals & $\begin{array}{l}\text { Historical objects. } \\
\text { High costs of transforming these objects, as well as } \\
\text { removal of pollution }\end{array}$ \\
\hline $\begin{array}{c}\text { Recreational } \\
\text { areas and } \\
\text { facilities }\end{array}$ & $\begin{array}{l}\text { Hotels, bowling alleys, gyms. } \\
\text { Diversified interest of investors in facilities in cities and } \\
\text { in rural areas. Necessity to retrofit facilities }\end{array}$ \\
\hline
\end{tabular}

Source: Cunnigham, Klemmer 1995, p. 36-41.

From the perspective of local authorities, the possibility of using post-military assets may be an opportunity to change directions and increase the dynamics of development, which in previous periods could not be implemented due to: limited supply of land, high prices of plots, lack of land for investors and housing purposes, etc.

It should be also noted that the negative consequences of liquidation of a military unit exceed the capacity of local authorities. For this reason, as a rule, regional and central authorities, and in the case of EU Member States, also EU funds available under the cohesion policy aim at the improvement of the socio-economic situation in such locations. One of such EU initiatives was KONVER Programme - a follow-up to expenditures in 1991 and 1992 under the budget item for Perifra, a scheme instituted by the EU Parliament to finance pilot projects designed, among other things, to assist in the conversion of regions whose economies depend on defense industries and military bases. The Commission decided to launch KONVER in 1993 because the situation in some areas affected by declining activity in the defense sector was worsening (The European Commission Press Release 1993). Applications for assistance in 1993 accounted of the split of funds between the European Regional Development Fund (ERDF ECU 85 million) and the European Social Fund (ESF - ECU 45 million). In principle major infrastructure works and purchases of land were not to be eligible but it was designed to help to partially finance a wide range of measures in the following fields (The European Commission Press Release 6/4/1993):

- basic/advanced training for new jobs and qualifications, as well as employment subsidies;

- diversification of economic structures within a region, in particular by assisting the development of small and medium-sized businesses;

- improvements to the business environment and the services available to businesses, including financial services;

- promotion of innovation, application of know-how and technology transfers;

- conversion of sites previously used by the armed forces and development of new activities on these sites;

- restoration of the environment and rehabilitation of land previously used by the armed forces, especially dealing with past pollution damage;

- feasibility studies and models for conversion projects;

- cooperation, including exchanges of experience, between the different areas affected.

The new Länder of Germany were already eligible in 1993 for the assistance provided under KONVER. According to Operational Programme for Germany the aim was to facilitate the vocational reconversion of workers who lost their jobs due to reductions of the armed forces or to reduce activities of the armament industries. The ESF contribution in 1993 only was ECU 13.22 million allowing the retraining of 3,250 persons and the granting of recruitment and start-up aids for 1,200 jobs. The main beneficiaries were likely to be civilian employees made redundant by the allied forces or the German army (The European Commission Press Release $11 / 10 / 1993)$. KONVER was transformed into an annual program included in the Structural Funds budget 1994-1999 (over ECU 500 million), more than $40 \%$ was received by Germany (Guay 1998, p. 60). 


\section{EFFECTS OF LIQUIDATION OF MILITARY UNITS IN POLAND AFTER 1990 ACCORDING TO OWN RESEARCH}

In Poland, in 1990, military units were deployed in 256 garrisons. In subsequent years, as a result of the restructuring of the armed forces, the number of garrison was reduced, as a result of which the number of garrison was limited to just over 100.

In a survey conducted among 33 representatives of local government from the area, where the army was withdrawn, among others, the answer to the question of what negative effects of the liquidation of the unit were met by representatives of local authorities and how the areas and post-military sites in the communes are or will be used. Respondents assessing the liquidation of a military unit in their commune mostly assessed it "definitely negative" (39.4\%) and "rather negative" (33.3\%), while the answer "neither positively, nor negatively" was given by only $18.2 \%$ of them. The fields in which local governments most strongly felt the negative effects of the liquidation of the military units were the labor market (rising unemployment, falling employment), real estate market (property destruction), income situation (income reduction) and demography (population migration). In the context of a noticeable destruction of post-military property, the problem was the prolonged procedures of its sale, exchange, preventing the use of buildings and land for development purposes. In the short term, the negative effects of the liquidation of the army in the commune prevailed, while in a long-term the situation improved due to the development of post-military areas for production, housing and public utility purposes. The table below presents the situation in 10 communes that faced the effects of the restructuring of the armed forces in their area (see tab. 2).

Table 2. Examples of using post-military property in selected communes

\begin{tabular}{|c|c|c|}
\hline Commune & Type of object, post-military area & Ways of using military property \\
\hline Goleniów & $\begin{array}{l}\text { Post-military airport with } \\
\text { infrastructure }\end{array}$ & $\begin{array}{c}\text { The Szczecin-Goleniów International Airport located } 33 \mathrm{~km} \text { north-east of the center of Szczecin at the } \\
\text { national road No. } 6 \text { (Goleniów - Gdynia). Its range covers over } 1.6 \text { million inhabitants. In recent years, a } \\
\text { new air traffic control tower and terminal have been built }\end{array}$ \\
\hline Grajewo & $\begin{array}{l}\text { Grounds and post-military } \\
\text { buildings }\end{array}$ & $\begin{array}{l}\text { Destination of the area for the needs of housing, restoration of historic buildings. Modernization and } \\
\text { improvement of technical infrastructure. Some buildings were adapted for: vocational school, fire station, } \\
\text { police headquarters }\end{array}$ \\
\hline Gubin & $\begin{array}{l}\text { Grounds and post-military } \\
\text { buildings }\end{array}$ & $\begin{array}{l}\text { The buildings were adapted for: a day care center for pensioners, communal and social housing, detention } \\
\text { center. In addition, the Catholic Association operates in the barracks building }\end{array}$ \\
\hline Międzyzdroje & Barracks, bunkers & $\begin{array}{l}\text { Execution of demolition of post-military buildings, arrangement of the area in the Międzyzdroje Forest } \\
\text { District. One of the bunkers developed into a museum }\end{array}$ \\
\hline Mrągowo & $\begin{array}{l}\text { Military barracks, } \\
\text { training blocks (14 ha) }\end{array}$ & $\begin{array}{l}\text { Some of the buildings have been renovated and handed over to schools. The rest are adapted for housing } \\
\text { and municipal institutions (ice rink, indoor swimming pool) }\end{array}$ \\
\hline Nasielsk & $\begin{array}{l}\text { Grounds and post-military } \\
\text { buildings ( } 9 \text { ha) }\end{array}$ & $\begin{array}{l}\text { In the post-military area, a museum center was created for exhibits of military technology, in which } \\
\text { military equipment and vehicles are presented. In hangars, in which anti-aircraft missiles were stored } \\
\text { and armed, on the surface of approx. } \mathrm{m}^{2} \text {, the most valuable military equipment was collected. Since } \\
2010 \text {, International Meetings Oldtimer Militaris have been held here, during which there is an exchange } \\
\text { of military items. The Foundation for Environmental Protection also operates in this area. It deals with } \\
\text { the protection of the environment and raising funds, cooperates with defense formations, supports state } \\
\text { and local government institutions in the event of natural disasters and catastrophes as well as performs } \\
\text { exercises in this area }\end{array}$ \\
\hline Piła & $\begin{array}{l}\text { Post-military airport, military } \\
\text { compound shooting centre, etc. } \\
\text { (650 ha) }\end{array}$ & $\begin{array}{l}\text { Part of the airport grounds is used by the aero club, the rest can be used for civil aviation purposes. In } \\
\text { the area of the airport a few institutions were located, such as a college of the university, provincial traffic } \\
\text { center. In the barracks, vocational school was also located. } \\
\text { Some of the buildings are used for the housing purposes. In addition, the land is used for economic } \\
\text { purposes, including commercial and service purposes. } \\
\text { The district court is located in the buildings and it is planned to extend and modernize the facilities and } \\
\text { the area of the Caritas Charity and Care Center. It is planned to build a tactical hall and modernize the } \\
\text { shooting facilities, also for the needs of the police school }\end{array}$ \\
\hline Pleszew & Post-military grounds (10 ha) & $\begin{array}{l}\text { Post-military real estate (didactic buildings, administration, boarding school, canteen, training workshop, } \\
\text { library, clinic, carpentry workshop) adapted by the Center for Education and Upbringing performing } \\
\text { educational, socialization tasks in relation to neglected youth and employment tasks in relation to } \\
\text { unemployed youth. In addition, a company was created to manage sports facilities }\end{array}$ \\
\hline Słubice & Military compound & $\begin{array}{c}\text { In the 1990s, Special Economic Zone was established within area and grounds for single-family housing } \\
\text { were earmarked. In the barracks there are currently: a parking lot, student houses of Collegium } \\
\text { Polonicum, a sports hall, poviat labor office, high school, city hall, district prosecutor's office, housing } \\
\text { estates }\end{array}$ \\
\hline Wałcz & $\begin{array}{l}\text { Barracks (also kitchen and } \\
\text { canteen, stables, bunkers) of } \\
\text { a former military unit, Wojska } \\
\text { Polskiego Street }\end{array}$ & $\begin{array}{l}\text { Some of the barracks and administrative buildings, including the gym, were transferred to the needs of } \\
\text { the Higher Vocational School. } \\
\text { Other facilities have been given service functions so far (wholesalers, transport services, car wash and } \\
\text { vulcanization). }\end{array}$ \\
\hline
\end{tabular}

Source: own elaboration based on local authorities' websites, local strategies and revitalization plans. 


\section{LOCAL REVITALIZATION PROGRAMS IN POLAND AS INSTRUMENTS OF LOCAL DEVELOPMENT AND RESTRUCTURING}

In the early 2000s, revitalization was defined as: a sequence of planned activities aimed at economic recovery and a change in the spatial and functional structure of degraded areas of the city, very often connected with post-military areas (Kaczmarek 2001, p. 16). According to laws applicable in Poland today, especially Act on Revitalization from 2015 (Act 2015, art. 1.2), revitalization is a process of deriving degraded areas from the crisis (so-called recessionary state) that should be run in a complex manner and territorially concentrated, through integrated activities undertaken for the local community, space and economy. What must be stressed here is that degraded areas are no longer understood as areas that need renewal of public places or infrastructure, but are designated as such due to the concentration of negative social phenomena (in particular unemployment, poverty, crime, low education or social capital, as well as insufficient participation in public and cultural life), accompanied by at least one out of the following spheres: economic, environmental, spatial-functional and/or technical. The negative occurrences in spatial-functional sphere include, in particular, presence of degraded and unused post-military areas and facilities. Planning of all revitalization undertakings should be preceded not only by the designation of the areas with high concentration of negative phenomena as well as its local potentials (Jadach-Sepioło 2016, p. 74).

All undertakings aimed at counteracting the concentration of problems in the degraded area should be based on the communal revitalization program and carried out by local stakeholders. Preparation, coordination and creation of conditions for conducting revitalization, as well as its management is a task of local self-governments of communes (Act 2015 , art. 3.1). Revitalization should show the way that problems can be solved or reduced; therefore it is a tool for community development. First stage of preparation is conducting diagnosis of a state of the commune taking into account social sphere and accompanying problems. Local (communal) revitalization program is a document prepared for the area of revitalization, which: may cover all or part of the degraded area in the commune, it must be characterized by a special concentration of negative phenomena relevant for the degraded area, due to its importance for local development, it will be an area where the commune will conduct revitalization. Such area cannot be larger than $20 \%$ of the commune's area and inhabited by more than $30 \%$ of the population of the commune, but it may be divided into sub-areas, including sub-areas without common boundaries, and non-populated post-industrial areas, including post-military grounds, where negative phenomena occurred (Act 2015, art. 10). As previously stated, the prerequisite is that the actions to carry out in these areas contribute to counteracting negative social phenomena, in case of post-military areas followed by negative occurrences from spatial-functional sphere. Revitalization program consists of 14 parts, the most crucial ones include (Act 2015, art. 14): revitalization vision, goals and cor- responding directions; description of activities aimed at eliminating or reducing negative phenomena, including in particular a list of planned revitalization projects, stating for each project: name and indication of entities implementing, scope of performed tasks, location, estimated value, forecasted results along with the method of their evaluation in relation to the purposes of revitalization; estimated financial framework of the municipal revitalization program along with an estimate of financial resources from public and private sources.

As the majority of stakeholders implementing revitalization projects under the current EU financial perspective are looking for co-financing of these activities from funds available under the EU operational programs, it is necessary to take into account the laws connected with the EU cohesion policy realization, including the Guidelines issued by the Minister of Development in order to unify the conditions and procedures for implementing operational programs for 2014-2020 in the scope of projects realizing revitalization goals and processes. Above all, the idea of integrated projects should be mentioned. There are at least two projects related to each other thematically as part of a common goal to be achieved thanks to their implementation, the selection of which, for co-financing or implementation, is coordinated by the relevant institutions. Coordination consists in particular in defining the mutual relations between projects in terms of the conditions of their selection and evaluation or the provisions of agreements on co-financing of a project or decision on co-financing a project (Act 2014, art. 32.2). In practice, the necessity to implement integrated projects means that an infrastructure project can be financed from the European Regional Development Fund only under the condition of implementing a social project precisely related to it, for example, the renovation of a damaged building must constitute an adaptation to specific social goals (to serve as a location for an institution implementing projects serving the purpose of leveling out diagnosed social problems). It is not allowed to plan and implement only selective investments, focused solely on the rapid effect of improving the aesthetics of space, aimed purely at renovation or modernization activities, which do not result in structural (social, economic etc.) changes in the area of revitalization. The laws also stress the need for the delivery of meaningful social participation in the revitalization process.

As it was mentioned above revitalization plan is currently a kind of estimate for the use of EU funds for the development of problem areas in communes, but funds for the implementation of revitalization projects, like other development projects, can come from various sources. The main source of financing are public funds. They include both financial instruments created by local authorities (e.g. local taxes, loans, bonds, etc.) and external instruments (national programs, e.g. for protection of monuments, building health, educational infrastructure, vocational retraining etc.). Another category are private sources, the acquisition of which involves the involvement of public authorities in creating a climate to invest, creating cooperation between the private and public sectors (including partnerships). Since Poland's accession to the EU, funding for projects has been provided through repayable 
measures (such as the JESSICA) and non-repayable EU funds (funds available under national and - above all - regional operational programs). Today, some of these funds are available only for the implementation of revitalization projects and the basis for their granting is, among others, the inclusion of the project in the local revitalization program prepared according to given guidelines and accepted by the institution managing the EU funds.

\section{CASE STUDIES}

Dislocations of military units in the period after system transformation took place at different times, hence the level of advancement of efforts to eliminate their effects and adaptation of areas to civilian targets is at various levels of advancement in individual communes and communes. Therefore, there are no planned actions to eliminate problems caused by dislocation or adaptation of former military sites in the current revitalization programs concerning some of the communes analyzed above (Goleniów, Grajewo, Gubin, Słubice), while, based on the analysis of the programs that were in force for quite recently (2007-2013), these activities were very important and intensified. In some programs one can find just some references to the presence of the army in the commune in the past, for example in Nasielsk among the local stakeholders and important entities of the NGO sphere there is an association of former soldiers.

In the half of the analyzed cases, in current revitalization programs, however, it is still possible to find activities related to the management of post-military property and the elimination of social or economic problems related to the dislocation of a military unit. Activities associated with these goals have a different role in these documents. In some, they are relatively small compared to all activities aimed at revitalization of problem areas (Mrągowo), however, there are cases where their importance is crucial for the implementation of a vision of development of a given degraded area (Piła, Wałcz).

The first group includes programs drawn up for communes Międzyzdroje, Pleszew and Mrągowo, where projects connected with adaptation of the post-military buildings for the purposes aimed at creating new infrastructure and eliminating social (like dependence on social assistance) and economic problems (like creating new jobs, e.g. in tourism) were designed. The idea of integrated projects can be illustrated here based on the example of a project entitled "Reconstruction and adaptation of the historic weapon storage, located in the former post-military area, for the Local Activity Center" included in Local Revitalization Program for the Town Mrągowo from 2016, developed to identify and plan priority revitalization projects for 2016-2023 (Mrągowo 2016, p. 4). With almost 22 thousand inhabitants, the town of Mrągowo is located in the north-western part of Poland. The town is a popular tourist and recreational center in Masuria, the socalled Polish land of a thousand lakes (there are three large lakes in the city) and is known mainly for the annual Picnic Country organized since 1982. Since 1955 the 9th Training Center for Communication Professionals has operated here.
In 2002, military unit in Mrągowo was disbanded, only the Military Training and Conditioning Center remained until today. Previous revitalization programs implemented by the commune resulted in the revitalization of the former military unit areas in $90 \%$ (some of the buildings have been adapted for economic activity, private apartments, 122 municipal and social dwellings were prepared). The area of revitalization was determined using index analysis. One of the significant problems in the social sphere was the diagnosed large number of people addicted to social assistance benefits. Also the share of long-term unemployed among persons of working age was relatively larger in this area than recorded for the whole commune. Indicators related to crime and alcoholism were at a worse level as well. As for the infrastructure sphere, this area is characterized by an above-average share of old and devastated buildings. The building of the weapon warehouse (Kopernika Street) is one of two buildings of former military unit that have not been revitalized, the area is undeveloped and unused, the building itself is in poor technical condition. The goal of the project is to strengthen local activity and create appropriate conditions for its integrated development, giving degraded sites new functions. The project will be managed by commune. The Local Activity Center will be an institution whose activity will serve for: a) development of comprehensive support programs addressed to marginalized, disadvantaged people living in the area, b) implementation of innovations in the field of self-organization, self-help and social activity of residents, including the development of volunteering and social entrepreneurship, c) improvement of intersectoral cooperation - institutions, organizations and other entities - for integrated revitalization projects. The list of activities to be undertaken in the Centre was designed. To make possible its realization three floors of the building will be renewed. On the ground floor, a multifunctional hall will be created, equipped with multimedia and conference equipment, enabling the organization of meetings, exhibitions, concerts, workshops, screenings and film projections, as well as allowing to conduct various thematic activities dedicated to the disabled, elderly people, children and parents, young people and other social groups. At the level of the first floor, there will be facilities for non-governmental organizations: office rooms, a workshop and a mini-conference room. On the second floor youth activity space is planned. In addition, accommodation space will be created in the attic, which, thanks to interior design, can also be used as a place for individual conversations and meetings in small groups (Mrągowo 2016, p. 103). The project improving the conditions for living and recreation of residents, as well as serving the development of tourism is the construction of a covered swimming pool in the area of former military unit.

In the group where projects concerning post-military areas and problems related to dislocation of an army unit are essential for the implementation of a vision of development of the whole degraded area revitalization programs of Piła and Wałcz communes were included. The example of Piła will be described, as it is a bigger city where the post-military areas constitute five sub-areas of revitalization located around the city center of Piła and cover the area of about 546 ha. The 
city self-government of Piła has been actively engaged in revitalizing activities since 2000. In the years 2004-2012, different revitalization programs were prepared for post-military areas, nevertheless, references to the revitalization of post-military areas are very visible in the current program prepared in accordance with the above described Polish regulations in force since 2015 (Piła 2018, p. 5 and 44). The city of Piła, which currently has over 73 thousands inhabitants, is located on the border of two lake districts, by the river Gwda, in north-western Poland, in the Wielkopolskie Voivodeship. Municipal rights were most probably received in the fifteenth century and today the city is one of the four major economic centers in the region and the largest in the north of the voivodeship. The largest company, employing over 5 thousand people, is Philips Lighting Poland S.A. In the north-western part of the city a large airport is located, until recently it had been used by the army. The area of revitalization included areas inhabited in the city center and western part of the city, where the high concentration of social problems was diagnosed (e.g. demographic burden - post-working age people account for almost $25 \%$ of the total population, also the unemployment and poverty is included in the significant problems of the area - the highest share of the unemployed and socially disadvantaged people was recorded here compared to all neighborhood areas in Piła, the results achieved by pupils are worse than in other parts of the city, people are less active when considering both their participation in social and economic life. Spatial, infrastructural and technical problems are also visible (Piła 2018, p. 32-33). Post-military terrains are partly located in the above described area - like for example a sub-area of the former Military Officer Automotive School, requiring further investments in the existing infrastructure. The area is intended for higher education, sports, recreation and tourism services. Its development will contribute to the increase in the number of jobs, which is especially important for the residents in the sub-area. This is crucial for counteracting other diagnosed negative social phenomena. The next sub-area is the ground of the former military compound - it has a varied terrain, and is partly wooded and deprived of equipment in technical infrastructure. A sub-area designated for economic and service functions, with the need to build road infrastructure. Its development will contribute to the increase of the potential for the development of economic functions, and thus the creation of new jobs. The area of the former military airport (with areas adjacent to the site as another sub-area of revitalization) was also included in the revitalization area. According to the defense plans of the country, the airport function is to be preserved. There is an urgent need for effective development of post-military facilities at the airport in order to prevent further degradation. In the sub-area there is the possibility of developing the airport function, e.g. as a local airport having basic infrastructure for the development of small air traffic (general aviation type), besides it is recommended to develop, in the sub-area, the functions of tourism, sport and recreation. Maintenance and development of the airport in Piła is an important factor of economic development and a significant stimulus for the improvement of the city. The fifth sub-area was added to the area of revitalization as a result of public consultations. Part of large-scale post- military facilities requires general modernization (the two largest buildings have already been modernized). The functions that are being implemented there include: education and justice, as well as commercial purposes, including trade. For this reason it should be recognized that the actions taken there will contribute to counteracting negative social phenomena (Piła 2018, p. 44-45). The list of revitalization projects includes: 25 projects aimed reducing social problems and 24 projects improving education conditions and developing culture; 16 projects aimed at economic elicitation and 7 improving communication; 15 projects connected with improvement of housing conditions, 8 projects concerning public spaces order and 7 projects concerning development of space for sport, recreation and culture. Among them, the projects related to the revitalization of post-military facilities must be indicated (Piła 2018, p. 54-90):

- a project related to the creation of the Sports and Educational Centre including, among others, comprehensive renovation and furnishing the premises of the facility constituting the former military kitchen and their adaptation to the purposes of the meeting room. The aim is to create an alternative to spending free time for young people, what will indirectly prevent the increase in acts of vandalism and aggression, as well as degradation of space and objects;

- 3 stages of an activity (constituting 3 separate projects of almost EUR 10 million investment co-financed from Wielkopolska Regional Operational Programme for the years 2014-2020) aimed at revitalization of post-industrial and post-military grounds for economic purposes - creation of industry zone South-East Piła;

- project connected with preparations of land around the post-military airport to locate and conduct business activity;

- project aimed at revitalization of airport facilities former air hangar, warehouse and utility building with the surroundings (expected outcomes: preservation of objects important for the city's history; improving public security through security; supporting local SMEs who actively use the landing pad and hangar by improving the technical condition and effective use of aviation infrastructure; creation of space for educational, cultural, sport and economic events; fostering environmental protection);

- project aimed at launching a civil airport for public use with limited certification in Piła (implementation of the project will affect improving connections of Northern Wielkopolska Voivodehip with the region; combined with a network of roads and railway it will create new communication options and ensure better spatial cohesion of the region and country);

- project conducted by one of the local historical societies aimed at improvement of the condition of anti-aircraft technical shelter located on Victory Square, resulting in extension of the object's educational function (grounds of such events as: live history lessons in originally preserved shelter from 1942);

- project for young people in Piła to be organized in facilities on the premises of the post-military airport, cyclical events such as: attractive glider training for children and adolescents, free simulator training, professional classes, consul- 
tations and workshops in the field of aeronautical modeling, construction of a flight simulator by members of the aero club, study trips and aero picnics for children and young people (expected results include: prevention of social exclusion, integration and activation of residents, educational benefits, developing active civil society attitudes, better access to cultural services).

\section{CONCLUSIONS}

The assessment of the presence of the army in the commune, and then its dislocation, is diversified and depends on the level at which it is carried out. The restructuring of the armed forces, in particular the liquidation of military units, from the municipal perspective may determine the negative effects for its development, as the army may be perceived as a catalyst for local development, and its dislocation means weakening the development potential of this place resulting from a decrease in the number of inhabitants, number of jobs, individual income, turnover, or the number of transactions on the real estate market. Due to the scale of negative local effects, overcoming social and infrastructural problems resulting from the dislocation of military units is a concern not only of local authorities, but also regional, central or even supranational (such as the EU support).

One of the instruments influencing local development are revitalization programs. In recent years in Poland, these programs have gained particular importance as a document constituting the basis for intervention from the EU funds. The analysis of local revitalization programs of selected communes has proven that post-military buildings can be an important infrastructure base for leveling social and economic problems of communes. Revitalization projects are now focused not only on improving the aesthetics of the former military units facilities, but above all enable the adaptation of objects to new civil functions, which gives an opportunity to improve the social and economic development of the revitalization area.

\section{REFERENCES:}

1. Act of 9 October 2015 on revitalization (O. J. from 2015, position 1777 with later amendments).

2. Act of 11 July 2014 on the rules for the implementation of programs in the field of cohesion policy financed in the financial perspective 2014-2020 (O. J. from 2014, position 1146 with later amendments).

3. Cunnigham, K.B., Klemmer, A. (1995). Restructuring the US Military Bases in Germany: Scopes, Impacts and Opportunities, Report 4, Bonn: International Centre for Conversion.

4. Guay T.R. (1998), At Arm's Length: The European Union and Europe's Defence Industry, Macmillan Press Ltd.

5. Intriligator, M.D. (2001). The Economic of Disarmament as an Investment Process. [in:] K. Hartley, T. Sandler (eds.), The Economics of Defence, vol. III.

6. Jadach-Sepioło, A. (2016). Local Development Factors in Urban Regeneration. Theorethical Approach / STUDIA REGIONALIA Journal of the Polish Academy of Sciences: Committee for Spatial Economy and Regional Planning \& European Regional Science Association (ERSA) Polish Section, Volume 46/2016, p. 73-87 [Electronic resource http://journals.pan.pl/ dlibra/publication/ 125785/edition/109758/content/local-development-factors-in-urban-regeneration-theoretical-approach-jadach-sepiolo-aleksandra?language=pl].

7. Kaczmarek, S. (2001). Rewitalizacja terenów poprzemysłowych. Nowy wymiar w rozwoju miast, Wyd. Uniwersytetu Łódzkiego, Łódź.

8. Markusen, A.D., Oden, M.D. (1994). Regional Adjustment of Defence Dependent Regions in the Post-Cold War Era, Paris: OECD.

9. Mrągowo (2016), Local Revitalization Program for the Town Mrągowo fot the years 2016-2023, [Electronic resource: https://bipmragowo.warmia.mazury.pl/5137/informacja-o-przyjeciu-dokumentu-pn.-lokalny-program-rewitalizacji-miasta-mragowo-na-lata-2016-2023.html].

10. Myrttinen, H. (2003). Base Conversion in Central and Eastern Europe 1989-2003, Paper 30, Bonn: International Center for Conversion.

11. Myrttinen, H. (2003). Base Conversion in Central and Eastern Europe 1989-2003, Paper 30, Bonn: International Center for Conversion.

12. Piła (2018), Revised Communal Revitalization Program for the City of Piła [Electronic resource: http://www.pila.pl/ $\mathrm{pl} / 190-$ rewitalizacja.html].

13. Piotrowska-Trybull M. (2013), Jednostki wojskowe w rozwoju lokalnym w Polsce po roku 1989, ZN AON, Warszawa: AON.

14. Sirko, S., Piotrowska-Trybull, M. (2013). Uwarunkowania lokalne i regionalne funkcjonowania jednostek wojskowych na terytorium kraju, Warszawa: AON.

15. Stankiewicz, W. (1999). Konwersja zbrojeń. Oczekiwania i fakty. Warszawa: Dom Wydawniczy Bellona.

16. The European Commission Press Release, 6/4/1993, Regional Policies: Commission Decides To Launch 'Konver'- A Scheme To Help Areas Affected By The Run-Down Of Defence-Related Industries And Military Installations [Electronic resource http://europa.eu/rapid/press-release_IP-93-267_en.htm].

17. The European Commission Press Release, 11/10/1993, KONVER: OPERATIONAL PROGRAMME FOR GERMANY [Electronic resource http://europa.eu/rapid/press-release_IP-93-847_en.htm]. 


\title{
THE IMPACTS OF MILITARY BASE CLOSURES AND REALIGNMENTS WITH SOME EXAMPLES BASED ON LOCAL REVITALIZATION PROGRAMS IN POLAND
}

\section{MARZENA PIOTROWSKA-TRYBULL}

Faculty of Management and Command,

War Studies University in Warsaw, Poland

m.trybull@akademia.mil.pl

\author{
ARANKA IGNASIAK-SZULC \\ Faculty of Economic Sciences and Management, \\ Nicolaus Copernicus University in Toruń, Poland \\ aranka@umk.pl
}

KEYWORDS: MILITARY BASE CLOSURES AND ALIGNMENTS, LOCAL REVITALIZATION PROGRAMS IN POLAND, REVITALIZATION PROCESS.

For citation: Piotrowska-Trybull, M., Ignasiak-Szulc, A. (2019). The Impacts of Military Base Closures and Realignments With Some Examples Based on Local Revitalization Programs in Poland, Globalization And Business, №8, pp. 170-177. https://doi.org/10.35945/gb.2019.08.022

\section{SUMMARY}

The literature in the field of economic sciences analyzes the role of military base (unit) on socio-economic development in many perspectives and scales but the local perspective is especially important as the location of military units has significant social, economic and spatial impacts and favors establishing relations between army and local entities, in particular self-government authorities, educational institutions, non-governmental organizations and residents. That is why also military base closures and realignments have prompted some of the most vocal public concerns in surrounding communities. The actual magnitude of local effects connected with closures is usually difficult to estimate, and is based primarily on case studies with some attempts to use statistical analysis in limited range (like employment).

The other issue described in the literature is connected with the process of revitalization (recovery) of local communes. One of the instruments of programming the process of so-called mitigation of crisis in the degraded areas has been the local revitalization programs in Poland in recent years. Literature and empirical evidence proves that the closure and alignment of a military unit results in some socioeconomic distress for community and it may be a decisive factor for the emergence of situations in certain areas characterized by the concentration of negative social problems and the occurrence of other negative phenomena (in the economic, environmental, spatio-functional or technical sphere) what is a prerequisite for marking the revitalization area according to Polish law. The EU-financed projects designed in the program should provide an assist to aid community revitalization efforts.

This article analyzes examples of local revitalization programs in communities where the military unit was closed. The aim of the case studies will be not only to learn about the actual impacts in the community and the proposals for minimizing those impacts, but also the assessment of the usefulness of the analysis of these planning documents to determine the socio-economic and spatial impacts of military dislocation on the local scale. 